\title{
On universalism in connection with the interpretation of magic in the semiotics of Juri Lotman
}

\author{
Peet Lepik \\ Department of Culture, Tallinn Pedagogical University \\ Lai 13, 10133 Tallinn, Estonia \\ e-mail: signans@hot.ee
}

\begin{abstract}
The article examines the first phase of the universalistic interpretations in Juri Lotman's semiotics, which is characterized by holism and maximalism derived from the Saussurean cultural concept. There is an analysis of Juri Lotman's 1967 lecture, previously unpublished, where universal status is accorded to text functions (including magic functions). Such an approach is a substantial revision of the Saussurean understandings of the relationship between language and speech. This interpretation of magic is compared with the examination of the same concept in Juri Lotman's 1981 article "Contract and self-sacrifice as archetypical cultural models", which substantially contradicts the concept developed in his 1967 lecture. Both these magic models produce a number of objections, and apparently seem to bear the deforming traces of their respective universalistic theoretical schema.
\end{abstract}

The aim of the present article is to provide an assessment of the first phase of Juri Lotman's universalistic endeavors using the example of the interpretation of magic. This task is particularly interesting for three reasons. Firstly, Juri Lotman has two conceptual schemas for magic, one of which was completed in 1967 (referred to as Mg 1), and the other (Mg 2) was published fourteen years later (Lotman 1993 [1981]), and the interpretation of magic in $\mathrm{Mg} 2$ is notably different to $\mathrm{Mg}$ 1. Secondly, $\mathrm{Mg} 1$ is one of the first attempts in the universalistic interpretation of culture in Juri Lotman's semiotics, and, thirdly, Mg 1 has never been published.

$\mathrm{Mg} 1$ is actually a fragment of notes taken during the series of lectures held at the University of Tartu. I came across the notes in 
1968. ${ }^{1}$ The general title of the lectures was "The semiotics of the individual and society" (Lotman 1967c). In my opinion, these notes are an interesting source and description of the early notions of Juri Lotman on the universals of culture in general. The notes indicate that there were four lectures, and they were held in the 1967 autumn semester. A text critical comparison permits the claim that the second and probably also the missing third lecture reproduce fragments of an article, which was published just before December 1967 (Lotman 1967a: 34-38). This same topic — now in written version in the "Lectures" was also used by Juri Lotman in writing his article "The problem of signs and the sign system, and the typology of Russian culture, 11th-19th centuries" (Lotman 1970a). (The latter is dedicated to the study of the projective semiotic relationship between language and culture.) $\mathrm{Mg}$ 1, which can be found in the fourth and last lecture held on December 22, 1967, has rather a loose association with the first part of the lecture series (except for the first lecture). In Lecture IV, Lotman is feeling his way regarding the possibilities of creating a universal typology of texts and text functions. One of the "building blocks" for this typology is indeed magic. (An excerpt of Lecture IV is included as an Appendix to the present article.)

We need to begin with the central concept: universal and universality. According to the task set in this article, I shall attempt to shed light upon this concept in the way it was expressed in the semiotics of Juri Lotman, just prior to the creation of the Tartu-Moscow school. A detailed theoretical analysis of Lotman's universalism presumes systematic study of all the relevant writings by the scholar and his coauthors.

The ideas and conceptual principles of Juri Lotman's semiotics are dynamic, hard to grasp and to define. Regarding our present topic, we can see that although the universalism theme is present in some form or another throughout Lotman's semiotic heritage - either as an important motive, background or facet - no monographs with information on the development of this topic have been published by him.

${ }^{1}$ The lecture notes were taken and given to me to read by Marju Lauristin. I rewrote them, without changing the punctuation or other characteristics of the language of the notes. According to Marju Lauristin, the original of the lecture notes no longer exists. Unfortunately it has not been possible (after initial enquiries) to find any notes from the third lecture, which Marju Lauristin did not attend. 
There are also no other authors who have written a monographic critique of Lotman's universalism. These other authors of course include Lotman's co-authors, primarily Boris Uspenski, Vyacheslav Ivanov and Alexandr Pyatigorski, together with whom, or having being directly inspired by whom, the Tartu professor has written cultural semiotic works, where the universalistic treatment dominated or was substantially represented. ${ }^{2}$

At the 2nd summer school of semioticians in August 1966 at Kääriku, Juri Lotman formulated for the first time the need for a description of the universals of culture and the compilation of an applicable "cultural grammar" (Lotman 1966: 83). In the introduction to the compendium of the summer school's presentations, the organizers indicated the need to differentiate with particular attention "those most general elements whose universality may assist in the common description of the various systems to be modeled" (Zamechaniya 1966: 4-5). The need for such a task was argued by Juri Lotman in his 1967 article "On the Problem of Cultural Typology". The article was published in volume 3 of Sign Systems Studies (Lotman 1967a). In the editors' foreword to the collection, Juri Lotman wrote of a methodological foundation for a cultural grammar (Lotman 1967b). In this introduction he sets out his understanding of cultural universals in radical opposition to Hegel's philosophy of history. As Hegel believed, the concept of world is realized at each stage of its development in only one national culture, which at that moment, from the standpoint of the world's historical process, is unique. But a unique phenomenon, argues Juri Lotman, can have no special feature - this requires that there be at least two systems for comparison. This is why the Hegelian concept of history not only emphasizes but even makes the differences between the epochs absolute. Everything that is not a difference in the comparison of epochs is left unmarked, because it is

${ }^{2}$ One of Juri Lotman's co-authors, Boris Uspenski, in his thorough theoretical work on the problem of universals, has remained within the limits of linguistics (Uspenski 1963; 1965; 1970). In implementing universalistic analysis in cultural semiotics, the joint work of Juri Lotman with Boris Uspenski which began in the 1970s is particularly noteworthy (Lotman, Uspenski 1971; 1973; 1975; 1982; 1994). With Alexander Pyatigorski he published in this context an important analysis of the semiotic relationship between text and function (Lotman, Pyatigorski 1968). The work by Vyacheslav Ivanov regarding the reflection of the psychophysiological functions of the left and right brain hemispheres in the basic codes of culture (Ivanov 1978) was extensively developed by Juri Lotman in his later articles (Lotman 1983; 1984; 1990) and elsewhere. 
not noteworthy. Lotman postulates that this is why it is important in principle to not deny the existence of other, possible non-human civilizations. Only the imagined viewpoint of an external culture enables the development of a typology for human culture as a whole. "That which is common to all epochs and civilizations - such a neutral element, not containing information, changes the specifics of human culture to a source of information" (Lotman 1967b: 6). In the course of such study, it is unavoidably apparent that some of the typological characteristics of culture are characteristic for whatever human culture, but some do not suit the common typology. These "most general characteristics", which unify cultures and are characteristic for human culture as a whole, are described by Lotman, in his methodological introduction, as cultural universals (Lotman 1967b: $6)$.

In the already mentioned second publication of the same collection, Juri Lotman states directly that the task of cultural typology is

[1] the description of such basic types of cultural codes, which form the basis for the languages of the various cultures and their comparative characteristics; [2] the determination of the universals of various human cultures, and as a result [3] the creation of a unified system of the typological features of the basic codes of cultures and a general structure of the universal features of human culture. (Lotman 1967a: 31; my emphasis and numbering, P. L.)

The described logic of research, in the opinion of Juri Lotman, would enable the creation of a "cultural grammar", and this would "hopefully lay the foundation for moving on to the construction of a structured history for culture" (Lotman 1967a: 34).

The object and the subject of this program, from the standpoint of the history of the Tartu-Moscow semiotic school, has quite a unique place.

Regarding the object of the research, the program can be described as a call to turn away from genre, compositional or other semiotic problems, specific to literature, folklore (myth) or religion, to the study of the major and general issues of culture - to cultural semiotics. (Nevertheless, the "special attention" of the second summer school was concentrated on texts, and limited to the examination of single problems; see Zamechaniya 1966: 4). At first glance it seems that cultural semiotic (text $=$ culture) subject matter is primarily (?) the personal field of interest for Juri Lotman and Boris Uspenski. Cultural semiotics became the common basic problem for the Kääriku group in 
1970, when the work of the fourth summer school was concentrated on studying the "unity of culture" - cultural semiotics par excellence (Predlozheniya 1970: 3; cf. Chernov 1988: 13). And three years later, in 1973, the "Theses" was published, which was considered the policy document for the school (Ivanov et al. 1998), ${ }^{3}$ and where cultural semiotics, which studies a certain unity of a person's informational activity, is termed "the study of the functional correlation of different sign systems" (Ivanov et al. 1998: 33). (It should be added that the introductory paragraph 1.0.0. of "Theses", which is quoted here, is to a great extent in accordance with both the content and wording of the aims of the Fourth summer school, which were probably prepared as an introduction to the summer school compendium by its editor Juri Lotman. This wording hints at the attempt to interpret cultural semiotics in a universalistic key.)

In the 1966/1967 policy positions, Lotman accentuates universalism with untypical maximalism and with laconic conviction. ${ }^{4}$ The field and methods of his research into universalism changed repeatedly over the years, "grammatical" rigidity was replaced by a more flexible and dynamic approach, but the discovery of the "mechanisms" of culture, whereby human cultures are similar, remained a common subject in Juri Lotman's scientific works to the end of his life.

The starting point for universalistic research is for him clearly associated with Ferdinand de Saussure's holistic language concept (for more detail see Mihhail Lotman's article in this volume). This expressed the hope of also discovering in other modeling systems a stable identity for grammatical categories which is characteristic of natural language: "A system, which is not organized in this way, is not a language, this means that it cannot be used for the preservation and transmittal of information". Such a feature of secondary modeled systems, in Juri Lotman's opinion, makes it possible to speak of the

3 "Theses" — and this was not coincidental — was not published in the Soviet Union (not even in Tartu), but in the space of one year in Poland, the Hague, and Paris. The Brezhnev reaction had accelerated.

${ }^{4}$ To date, Lotman had examined / was examining two universalistic problems: the aesthetics of sameness and difference in an artistic text (Lotman 1994: 222232), and the structural role of beginning and end in cultural texts (in culture) (Lotman 1966: 69-74). Boris Uspenski, and Alexander Pyatigorski, who joined him in 1967, moved in the direction of cultural typological "invariant schemas" (Zamechaniya 1966: 4) with their personological analyses (Uspenski 1966; Pyatigorski, Uspenski 1967). 
existence of the "universal constants" of language (code), which guarantee its identity (Lotman 1967b: 6).

These methodological points of departure lead Lotman (together with some colleagues) to treat object-language and meta-language as phenomena of one and the same level, or (as characterized, after the fact - and as self-criticism - by Alexander Pyatigorski) "to the naturalization of culture, to treating culture as 'Nature", (Pyatigorski 1994: 326). In Juri Lotman's eyes, this rebuke became rather a challenge, but the description of its later fate cannot unfortunately be included in this article.

The most extensive "naturalized" analysis of the universal constants characteristic of culture during the period under observation is presented in the article "The problem of signs and sign systems, and the typology of Russian culture, 11th-19th centuries" (Lotman 1970a) and "The semiotics of the individual and society" in Lecture IV (incl. Mg 1) (Lotman 1967c). In the former, the various types of Russian culture are examined as the historically changing realization of various cultural codes. The codes combine, form hierarchies and "infiltrate more and more the deep legitimizations of the structure of sign systems". In every culture, some (few) of the codes always become dominant. The dominance phenomenon is explained by Lotman, saying that "the communicative systems are also modeling systems and a culture, in constructing a model of the world, also creates a model of itself" (Lotman 1970a: 12-13).

In the second universalistic analysis, which is Lecture IV, Juri Lotman proceeds from the understanding that text and the immanent rules (code) that determine its structure are not sufficient to decipher the text, or are even useless. He introduces the phenomenon of function, which can change the meaning of the text completely. In $\mathrm{Mg}$ 1 he interprets culture as a collection of social functions. This however means leaving the immanent structure of the text. Lotman provides certain functions a universal status. According to him, function,

- is a permanent abstract construct which survives the texts (as is language in relation to speech)

- is autonomous regarding text

- is realized in texts as a relationship between speaker and listener. This is interpreted via expressive and illocutive terms, which permits the treatment of the speaker-listener relationship as a position of mutuality.

- is consequently typologically describable. However, space and time features are considered by Lotman as those "most general of elements, whose 
universality may simplify the common description of various modeling systems" (Zamechaniya 1966: 4-5).

- in science and in practice (here as non-signed), it becomes apparent from the texts of the speaker; through the texts of the listener, the function becomes apparent in the form of religious or magical relations. (See excerpt of the IV lecture in the appendix of the present article; Lotman 1967c.)

Juri Lotman, in his Lecture IV, has thus interpreted magic, religion, science and (separately) art as social functions, which are realized topologically and communicatively. The noted functions as abstract constructs are of a universal nature, which generate cultures, and span the historic and geographical boundaries of cultures. Functions live longer than texts, and may in principle adapt to any text whatsoever. I consider this schema by Juri Lotman as a theoretical idea with great potential (despite the fact that in my opinion the religion and magic concepts in Lecture IV have been imprecisely treated).

The uniqueness of the 1966/1967 program is also apparent in another fact, which appears for the first time soon after $\mathrm{Mg} 1$ was completed. On closer inspection, it can be seen that neither in the Third Summer School compendium (Letnyaya shkola 1968) nor in the Fourth Summer School compendium, which concentrated on cultural semiotics (not in the introduction (see Predlozheniya 1970: 3-5) nor in the compendium articles, including Juri Lotman's), are the terms universalism, cultural universal, human culture or the basic code(s) of human culture used any more. ${ }^{5}$ In the 1973 "Theses" these terms are also missing; in the place of human culture there is consistent emphasis on the heritage of Slavic culture. The word universal appears in "Theses" only once — in the description of the reconstruction of Slavic texts there is an off-hand comment that the highest purely semantic level being reconstructed "in the final analysis we transfer to the language of certain universal notions" (Ivanov et al. 1998: 47). In Mg 2, there is a comparison of the Russian and the western European legal systems (the latter being based on the Roman tradition), and there is also no rising to the level of "humanity".

${ }^{5}$ The adjective universal does however appear once in one of Juri Lotman's notes on the correlation between number and the types of culture, from which he says one can conclude that the paradigmatic structure of culture "encourages the transformation of number into a universal symbol of culture" (Lotman 1968: 107). By the way, in the Summer School III compendium there is no Foreword. Such an introduction (usually worded by Juri Lotman) usually emphasized the general goals and unifying concepts. 
In this development logic, which may initially seem paradoxical, there are a number of converging facts. At first glance they seem to indicate that Juri Lotman was distancing himself from the study of universalism. But it is more likely that this was a quite sudden change to a more moderate position, but after a certain delay subsequent to the completion of $\mathrm{Mg} \mathrm{1.} .^{6}$ Lotman did not want to follow in the footsteps of those scholars who use "impressionism" on a higher level of research as a replacement for the precise study of text on an elementary level (Lotman 1969b: 480). He distances himself clearly from static models which had acquired a bad reputation in structuralism, and emphasizes that the internal and contextual (incl. energetic and dialogical) correlations of cultural texts demand a very thorough multilevel analysis of both the static and dynamic structures. The interpretation of the dynamics of the text results in conflict with the principle of "grammatical unity", which results in Lotman starting to search for more abstract universalistic features for texts (culture) (Lotman 1969b: 478-480).

In his article "On the metalanguage of a typological description of culture", Lotman undertakes an analysis which is in accordance with such criteria. He describes the typological features of the universal space models of culture (Lotman 1969a).

In the analysis of $\mathrm{Mg} 2$, magic is already treated in the form of such a typological model, where the magical function is a higher-level text in relation to text(s) - in a way, a metatext (Lotman 1993). In the case of $\mathrm{Mg} \mathrm{1}$, as I have already indicated, text and function were observed as phenomena on the one and same level: culture in such a case was transformed into a collection of functions, and the text(s) were derived from this (those) function(s) as elements of the same level (cf. Lotman, Pyatigorski 1968: 75).

If $\mathrm{Mg} 1$ and $\mathrm{Mg} 2$ are compared, not according to the method of study of culture, but according to the subject for the study of which the method is being implemented, then one is surprised by the fact that $\mathrm{Mg} 1$ and $\mathrm{Mg} 2$ contradict each other to a great degree. ${ }^{7}$ But it is not

6 To some extent we need to take into account that the planning and writing of two monographs on artistic texts (Lotman 1970b; 1972) in 1969-1971 apparently did not permit him to dedicate himself to the systematic study of the more general problems of culture.

Of course one needs to take into account, in the following comparison, the problems associated with a text critical assessment of the lecture notes in manuscript form. 
possible to accept, without limited or greater reservations, the content of either interpretation of magic.

$\mathrm{Mg} 2$ is characterized by four features. These are: (1) "bilateralism", i.e., both the parties in the magic act are in the roles of both subject ("speaker") and object ("listener"). (2) The parties enter into a "contract" relationship, which is characterized by (3) "compulsoriness" - both parties use power regarding the other, and (4) the "equivalence" (equilibrium) of conventional, signed relationships (Lotman 1993: 345).

In both $\mathrm{Mg} 1$ and in $\mathrm{Mg} 2$ there are the basic attributes of magic: the subject and object of the magic act, communication between them, its signedness (decipherability), the act and a certain power, the might which ensures the magic of the act.

As opposed to the "bilateralism", and the equilibrium of the "equivalent" exchange in Mg 2, the "magical situation" in Mg 1 is unilateral. One of the parties "thinks" that he is not able to "influence in a practical way" the other: he expects "an unexplained gift". He does create a "correlation" between himself and the "inexplicable power" "with some kind of act" in order to "deserve" it, but his hope is backed by an "opinion" that the intangible power cannot be influenced. This is reminiscent of Ludwig Wittgenstein, who in criticizing James Frazer's understanding of magic remarked that "the expression of a wish in magic is eo ipso the expression of its fulfillment". An opinion may be "flawed" (therefore also deserving of suspicion). But a "religious symbol", as is claimed by Wittgenstein (I would add here the magic index as well), "is not based on opinion" (Tambiah 1999: 58-59). ${ }^{8}$ It seems that placing a magic act in a rational context is not justified. ${ }^{9}$

The power controlling a magic situation, making something happen — the agens - is Mg 1's speaker, the "unknown power", in Lotman's terminology. The subject of the magic (the individual) is the listener. Lotman believes that a magic situation occurs only if the

${ }^{8}$ The manuscript by Ludwig Wittgenstein about James Frazer's concept of magic was published by Stanley Tambiah for the first time in his monograph, to which I have already referred (see Tambiah 1999: 54-64).

${ }^{9}$ In the opinion of Edmund Leach, the magic act is an index used by the magician as a signal where the effect can be interpreted as a Pavlovian dog reflex (Leach, 1991: 30). Essentially, the same claim has been made by Boris Uspenski (in a conversation with this author in Tallinn, 10.09.2002), where he compared the magical effect with the reflex action occurring after the knee has been tapped with a hammer. 
listener is not in control of the legitimacy, which is the basis for the speaker to "give" something that is "unexplainable". With his schema, Lotman deviates from the established traditions of the interpretation of magic (not to mention - although this in the future! - from his own Mg $2^{10}$ ) (Frazer 2001: 35-52; Jakobson 1968: 355; Nöth 1986: 391, 392; Nöth 1990: 147, 148). Juri Lotman's claim in Mg 1 that to be a listener is not "a remnant from the past" is indeed applicable to religion but not to magic. Magic is the performative act of a subject (Tambiah 1999: 58, 60), where the content is always the object being influenced indirectly (communication) and/or instrumentally, and which is "manipulation" with certain "supernatural" phenomena (Clark 1997: 282-283, 214-215).

In seeing the listener in the subject, Lotman is partially right. As I have attempted to justify elsewhere (Lepik 2001: 208-211), the subject has both a listening-function as well as a speaking-function; the listening-function is associated with the mythological structure of the magic agens, but the performative speaking-function with the agens's magic act itself. And the listening connects the agens with "history" - with the patrum more ritualized norms which the subject of the magic act must command.

This is the reason why, in analyzing magic, confusion can easily occur in defining the concept of the magician. One must also take into account that the concept of magician is on the one hand associated with something from the beyond, non-human (this is in accordance with Lotman's "unknown power"), but on the other hand, psychologists, culturologists and semioticians have indicated something that can be summarized by Tambiah's conclusion on Wittgenstein's analysis of Frazer: "Wittgenstein is claiming that 'civilized' man has within him the same symbolizing and ritualizing tendencies as the 'primitive'. This is synchronic and not an evolutionary posture (Tambiah 1999: 60). ${ }^{11}$ Moreover, Jean Piaget indicates that long before a child in his second year learns to substitute an unseen object, or a non-

${ }^{10}$ In one even later work, Juri Lotman associates the historic origins of speech with magic, thereby extending the performative speaker-role to the maximum (Lotman 1992: 20).

${ }^{11}$ However, J. Lotman, at the time and also later, did not confront the problem of the "beginning" of culture intentionally, although in his later works he provocatively claims that any "thinking" semiotic structure, in order to be launched, must definitely receive an impulse from another thinking structure: "Consciousness must be preceded by consciousness" (see Lotman 1990:399-400; Lotman 2000: 152). 
sensory event, with icons and symbols, the child relates to the outside world with the help of indexes, including signals, which create conditioning conditioning (Piaget 1970: 717). Piaget has elsewhere compared certain characteristic forms of the manifestations of a child's thinking with magic acts, and treated these as a natural step of a child's "pre-logic thought" (see Nöth 1990: 159).

Who is it then that can in a magical situation fulfill the role of an agens? Can it only be a power, which is from the beyond or "signed" in the beyond, or can it be any actant who steps into such a role? In my opinion, one can find an answer to this question in Boris Uspenski's detailed study which is dedicated to the history of the formation of the structure and functions of Russian expressive phraseology (the Russian $m a t^{12}$ ). The cultural function of magic as agens became more profane and "democratic", analogously to the way in which the fertilization of the Earth-Mother by the Heavenly-Father (Lightning God), ended up as a ritual with magic functions associated with the antagonist of God - the dog. Subsequently, the ritual was degraded even further - into obscenity. Functionally, all actants on a microcosmic level have a magic role (Uspenski 1994: 99-104). ${ }^{13}$ On the level of behavior, the magic features of the Russian mat are easily apparent, particularly to the "stranger". And the person turning on the television ends up immediately, as a victim of advertising, in the manipulating field of "magicians" (cf. Nöth 1990: 151-152).

Juri Lotman also contrasts magic and science as listener and speaker texts, emphasizing the procedural features of the speaker text. The procedural feature, however, is a determining characteristic of both structures, as has been consistently claimed in culturology, since the time of Tylor and Frazer (Frazer 2001: 54-55; Malinowski 1998: 76, 85, 86; Hoebel 1966: 470). The argument has only been about the magical procedures' causality-non-causality, genuineness-falseness, naturalness-supernaturalness, rationality-esotericity (Levy-Bruhl 1925: 42; Frazer 2001: 887-888; Malinowski 1998: 70-71; etc.).

The path-model, on which Juri Lotman bases his analysis of science, is analogous with magical proceduralism. For example, the

${ }^{12}$ It should be added as explanation that the lexemes mat' $=$ mother and mat must be kept separate. The latter signs in Russian a certain paradigm of expressive obscene expressions which have received their name from expressions where the object is mother.

${ }^{13}$ Boris Uspenski refers directly to magic relations on one level (Uspenski 1994: 103). 
individual progress of a Sufi for unification with God is indeed termed the path (ar. tariqa). This word also signs the concepts of method and procedure. ${ }^{14}$ The path is a step-by-step series of increasingly esoteric procedures (instructions) directed towards oneself, where each step is associated with carrying out ritualized acts (procedures) intended to achieve a certain goal. The relationship between the act and its goal does not formally differ at all from the structure of any other magic $\operatorname{act}^{15}$ (Arasteh 1970). Oswald Spengler does not err when he considers Islam to be a thoroughly magical culture! ${ }^{16}$

It is also questionable to differentiate between magic and religion according to the formulae "it is being done to me" — "I am being given the truth". Giving the truth may simultaneously be being done to me. And being done to me could also mean giving the truth. The observed confusion or inconsistency of Juri Lotman (and many other authors) in the identification of the (verbal) activity of magic (the subject) is associated with the fact that the structure of the agens is being looked at as being one-sided. It is usually not thought, as I already had reason to indicate previously, that a magician (subject $=$ speaker) in command of the agens is simultaneously engaged in two dialogues (for more detail, see Lepik 2001: 206-211). As the actant of the mythological structure of the agens, he is definitely associated with getting. Bronislaw Malinowski already indicated that the magician appeals to "ancestors and the heroes of culture from whom the magic has been gotten" (Malinowski 1998: 74; my emphasis, P. L.). But this is only one side of the magic procedure. The denominator of the other side could be considered to be I am doing and here the agens is manifested as an effective power. Such a purposeful performative activity has been described on the linguistic level by John Austin (1962). Following his lead, this was brought into the description of

${ }^{14}$ Franz Rosenthal, referring to al-Ghazali, writes "The views of various kinds of Islamic religious thinkers do not essentially differ amongst themselves regarding that which relates to practical methods and procedures (tariq al-"amal)" (Rozenthal 1978: 177).

${ }^{15}$ Haljand Udam indicates that "in the Semitic tradition, which also includes Islam, the word of God (logos) is grammatically in the imperative form and not a neutral noun" (Udam 1992: 125). According to Roman Jakobson's semiotic magic-schema, conatives are the elements that create the linguistic structure of magic (Jakobson 1968: 355; see also Lepik 2001: 211-212). By the way: the Sufis have understandably never described their views as "magic".

${ }^{16}$ It should however be noted that Oswald Spengler made his conclusions on the basis of other characteristics. 
magic by Roman Jakobson (1968: 355) and Edmund Leach (1991); see also Peet Lepik (2001: 211).

The dominate structural element of $\mathrm{Mg} 2$ is considered by Lotman to be contracturality (Lotman 1993: 345). One must firstly note that contracturality, bilateralism and equivalency, as features characterizing magic are partially overlapping mutual concepts. It seems that the characterization of magic using particularly these features has tended to be influenced by the attempt to construct, for the comparison of $\mathrm{Mg} 2$ and religious "self-sacrifice" a symmetric (4-4) and antithetic model (bilateralism (in magic) contra unilateralism (in a religious relationship); equivalency — its lack; being mandatory — its lack; contract - unconditional (self)sacrifice) (Lotman 1993: 345-346). But it is more important that contracturality does not unfortunately seem to be a mandatory feature of a magic act. Even using an intuitive assessment, one may be certain that the majority of magic texts are not contracts (with the devil). The opposite is also not confirmed by the tradition of magic study. In his article, Lotman does not argue the justification of this feature in the formal structure of magic as a universal relationship. He even avoids such a postulation of the question, and takes the analysis of magic into a much narrower framework contrasting the high value of contracturalism in Roman law with the low value of contracts in a Russian culture based on the spirit of Orthodoxy. The interpretation of contracts in the Russian cultural space could be considered most successful, original and interesting. The whole concept of the article seems indeed to be constructed on this analysis. The treatment of the Roman emperor cult as a magic"contractural" system does however create serious objections.

As a point of departure, it must be stated that in the name of, on account of and because of religion, contracts have always been made in every culture. Certain social issues, such as the propagation, propagating, assessing etc of various confessions must be differentiated from the formal structure of religious communication. If a contract (say with the devil) can be considered an immanent structural feature for certain types of magical acts, then someone's contract with Roman authorities regarding the recognition of the emperor cult can only be considered a political instrument for the propagation of the emperor cult or a political agreement.

If the basis for the assessment of the emperor cult is taken from the court recordings of the Christian martyrs' cases, and the bureaucratic formalism of the emperor cult, which the Christians have always used for the promotion of the virtues of Christianity, then one could truly 
be left with an impression of the contracturality of Roman emperor worship. The court recordings of the martyrs' cases are often compiled with an emphasis on the opportunity to be set free. The pattern is as follows: All you need to do is to "sign"/ "bring a sacrifice to the sacrificial altar" / "swear in the name of the god-like spirit of the emperor" / "sacrifice before the portrait of the emperor", by which you recognize the superiority of emperor worship (to Christianity), and you will save yourself and walk free! (Stauffer 1966: 205-207). "Thus the emperor worship was essentially not so much a matter of faith, as a matter of public order and discipline, a civil obligation for civilians and a service obligation for soldiers," is also Ethelbert Stauffer's summarization in the spirit of "contracturality", but as a convinced apologist for Christianity! (Stauffer 1966: 203).

The above conclusion must not lead us astray! Those people who had contact with the Stalinist cult remember all too well that in addition to the "service obligation" to worship Stalin, there was also a religious relationship which was strange and powerful, and which was responsible for the formation of the entire culture. This was clearly the case in Rome, if one reads carefully, for example, Ethelbert Stauffer's study, and takes into account Juri Lotman's words regarding the universality of the religious function. This is why it is not possible to agree with Lotman's 1981 conclusion that Roman emperor worship was not a religious but a magic system.

It is known from history that at least Caligula, Nero, Domitianus and Commodus actually considered themselves to be gods. Caesar's successor Octavianus received the additional name of Divi Filius (son of god). Henceforth the Roman emperor is called "Lord, our God", and he is considered, as is documented by Stauffer, the "bringer of grace", "godly Savior". Miracles are associated with the emperor, including the emperor "going to heaven" (Stauffer 1966: 201-202). In the throne room, "the gathering greets the "countenance of the most holy emperor' as if it were a revelation from another world. When he opens his mouth, all listen as if to a voice from the heavens. This is how the senate procedures become procedures for the worship of a god. There is a kind of parliamentary liturgy." Announcements of imperial orders in the provinces were preceded by formulations such as "the godly decision by our godly lord commands" or "the heavenly regulations of the godly command thus order" or "the godly mercy of the all-holy emperor does will". In all the major towns of the country imperial temples were erected with statues and altars in front of them, 
where sacrifices and incense were brought to the portrait of the emperor (Stauffer 1966: 202-203).

These features permit a description of the Roman emperor worship as also (or primarily?) a religious system which, according to all its characteristics, suits the "self-sacrificing" religious model constructed by Juri Lotman.

In conclusion, it could be said that the universalistic schema used in Juri Lotman's treatment of magic provide many promising analysis opportunities. But their specific implementation in the context of $\mathrm{Mg}$ 1 and $\mathrm{Mg} 2$ bears some traces of deformation in the research process.

\section{References}

Arasteh, A. Reza 1970. Patterns and processes of self-liberation in the Near Eastern sufism: Art of rebirth. Psychologia 13: 5-11.

Austin, John L. 1962. How To Do Things With Words. Oxford: Clarendon Press.

Chernov, Igor 1988. Historical survey of Tartu-Moscow Semiotic School. In: Broms, Henri; Kaufmann, Rebecca (eds.), Semiotics of Culture: Proceedings of the 25th Symposium of the Tartu-Moscow School of Semiotics, Imatra, Finland, 27th-29th July, 1987. Helsinki: Arator Inc, 7-16.

Clark, Stuart 1997. Thinking with Demons: The Idea of Witchcraft in Early Modern Europe. Oxford: Clarendon Press.

Frazer, James G. 2001 [1890]. Kuldne oks: Uurimus maagiast ja religioonist. Tallinn: Varrak.

Hoebel, E. Adamson 1966. Anthropology - The Study of Man. New York: McGraw-Hill Book Company.

Ivanov, Vyacheslav V. 1978 = Иванов, Вячеслав Вс. Чёт и нечёт: Асимметрия мозга и знаковых систем. Москва: Советское радио.

Ivanov, Vyacheslav V.; Lotman, Juri M.; Pjatigorski, Alexandr M.; Toporov, V. N.; Uspenski, Boris A. 1998 [1973]. Theses on the Semiotic Study of Cultures. (Tartu Semiotic Library 1.) Tartu: Tartu University Press.

Jakobson, Roman 1968 [1960]. Linguistics and poetics: Closing statement. In: Sebeok, Thomas A. (ed.), Style in Language. Cambridge: MIT Press, 350377.

Leach, Edmund 1991 [1971]. Culture and communication. The logic by which symbols are connected. Cambridge: Cambridge University Press.

Lepik, Peet 2001. Myth and magic as semiotic phenomena. In: Bernard, Jeff; Withalm, Gloria (eds.), Myths, Rites, Simulacra. Semiotic Viewpoints: Proceedings of the 10th International Symposium of the Austrian Association for Semiotics. [Angewandte Semiotik 18/19, vol 1.] Vienna: ÖGS, 201-216.

Letnyaya shkola 1968 = III летняя икола по вторичныцм моделирующим системам. Тезисы. Доклады. Кяэрику 10-20 мая 1968. Тарту: ТГУ. Lévy-Bruhl, Lucien 1925. La mentalité primitive. Paris: Librarie Félix Alcan. 
Lotman, Juri 1966 = Лотман, Юрий. О построении типологии культуры. In: Тезисы докладов во второй летней школе по вторичным моделирующим системам: 16-26 августа 1966. Тарту: ТГУ, 82-83.

- 1967а = Лотман, Юрий. К проблеме типологии культуры. Труды по знаковым системам (Sign Systems Studies) 3: 30-38.

- $1967 \mathrm{~b}=$ Лотман, Юрий. От редакции. Труды по знаковым системам (Sign Systems Studies) 3: 5-6.

- 1967c = Лотман, Юрий. Семиотика личности и общества. (The manuscript of nonpublished lecture, in possession of Peet Lepik.)

- 1968 = Лотман, Юрий. Семантика числа и тип культуры. In: III летняя икола по вторичным моделируюшим системам. Тезисы. Кяэрику 10-20 мая 1968. Тарту: ТГУ, 103-109.

- 1969а = Лотман, Юрий. О метаязыке типологических описаний культуры. Tруды по знаковым системам (Sign Systems Studies) 4: 460-477.

- 1969b = Лотман, Юрий. О некоторых принципиальных трудностях в структурном описании текста. Tруды по знаковылм системам (Sign Systems Studies) 4: 478-482.

- 1970а = Лотман, Юрий. Проблема знака и знаковой системы и типология русской культуры XI-XIX вв. In: Лотман, Юрий, Статьи по типологии культуры І. Тарту: ТГУ, 12-35.

- 1970b = Лотман, Юрий. Структура художественного текста. Москва: Искусство.

- 1972 = Лотман, Юрий. Анализ поэтического текста. Ленинград: Просвещение.

- 1983 = Лотман, Юрий. Асимметрия и диалог. Труды по знаковым системам (Sign Systems Studies) 16: 15-30.

- 1984 = Лотман, Юрий. О семиосфере. Труды по знаковым системам (Sign Systems Studies) 17: 5-23.

- 1990. Aju — tekst - kultuur - tehisintellekt. In: Lotman, Juri. Kultuurisemiootika. Tallinn: Olion, 394-410.

- 1992 = Лотман, Юрий. О динамике культуры. Труды по знаковым системам (Sign Systems Studies) 25: 5-22.

— 1993 [1981] = Лотман, Юрий. “Договор” и “вручение себя” как архетипические модели культуры. In: Юрий Лотман. Избранные статьи в трёх томах 3. Таллинн: Александра, 345-355.

- 1994 [1964] = Лотман, Юрий. Лекции по структуральной поэтике. In: Ю. М. Лотман и тартуско-московская семиотическая школа. Москва: Гнозис, 10-263.

— $2000[1990$ ] = Лотман, Юрий. Внутри мыслящих миров. In: Юрий Лотман. Семиосфера. Санкт-Петербург: Искусство СПБ, 150-390.

Lotman, Juri; Pjatigorski, Alexandr 1968 = Лотман, Юрий; Пятигорский Александр. Текст и функция. In: III летняя школа по вторичным моделирующии системам: Тезисы. Доклады. Кяэрику 10-20 мая 1968. Тарту: ТГУ, 74-88.

Lotman, Juri; Uspenski, Boris 1971 = Лотман, Юрий; Успенский, Борис. O семиотическом механизме культуры. Tруды по знаковьм системам (Sign Systems Studies) 5: 144-166. 
- 1973 = Лотман, Юрий; Успенский, Борис. Миф - имя — культура. Труды по знаковым системам (Sign Systems Studies) 6: 282-203.

- 1975 = Лотман, Юрий; Успенский, Борис. Споры о языке в начале XIX в. как факт русской культуры (“Происшествие в царстве теней или судьбина российского языка" - неизвестное сочинение Семена Боброва). Труды по русской и славянской филилогии 24: 168-322.

- 1982 = Лотман, Юрий; Успенский, Борис. "Изгой” и "изгойничество" как социально-психологическая позиция в русской культуре преимущественно допетровского периода. (“Своё" и "чужое” в истории русской культуры.) Труды по знаковым системам (Sign Systems Studies) 15: 110-121.

— 1994 [1977] = Лотман, Юрий; Успенский, Борис. Роль дуальных моделей в динамике русской культуры. In: Успенский, Борис А. Избранные трудыл I. Москва: Гнозис, 219-253.

Nöth, Winfried 1986. Semiotics of Magic in Children's Folklore. In: Deely, John (ed.), Semiotics 1985. Lanham: University Press of America, 390-400.

- 1990. Semiotics of Magic. In: Koch, Walter A. (ed.), Aspekte einers Kultursemiotik. Bochum: Universitätsverlag Dr. Norbert Brockmeyer, 141-163.

Piaget, Jean 1970 (1946). Piaget's theory. In: Mussen, Paul H. (ed.), Carmichael's Manual of Child Psychology 1. New York: John Wiley and Sons, 703-732.

Pjatigorski, Alexandr 1994 = Пятигорский, Александр. Заметки из 90-х о семиотике 60-х годов. In: Ю. М. Лотман и тартуско-московская семиотическая школа. Москва: Гнозис, 324-329.

Pjatigorski, Alexandr; Uspenski, Boris 1967 = Пятигорский, Александр; Успенский, Борис. Персонологическая классификация как семиотическая проблема. Tруды по знаковым системам (Sign Systems Studies) 3: 7-29.

Predlozheniya $1970=$ Предложения по программе IV Летней школы по вторичным моделирующим системам. In: Tезисы докладов IV Летней школь по вторичным моделирующим системам. Тарту: ТГУ, 3-5.

Rosenthal, Franz 1978 [1970] = Розентал, Франц. Торжество знания: Концепиия знания в средневековом исламе. Москва: Наука.

Stauffer, Ethelbert 1966 [1952]. Christus und die Caesaren: Historische Skizzen. München und Hamburg: Siebenstern Taschenbuch Verlag.

Zamechaniya 1966 = Замечания по программе занятии. In: Тезисы докладов во Второй летней школе по вторичным моделирующим системам, 1626 августа 1966. Тарту: ТГУ, 3-5.

Tambiah, Stanley J. 1999 [1990]. Magic, Science, Religion and the Scope of Rationality. Cambridge: Cambridge University Press.

Udam, Haljand 1992. Seletusi ja lisandusi. In: Tufail, Ibn. Elav ärganu poeg: Filosoofiline jutustus. Tallinn: Olion, 119-136.

Uspenski, Boris 1963 = Успенский, Борис. Universals of Language. J. H. Greenberg (ed): Рецензия. Вопросы языкознания 5: 115-130.

- 1966 = Успенский Борис. Персонологические проблемы в лингвистическом аспекте. In: Тезисы докладов во Второй летней школе по вторичнызм моделирующим системам, 16-26 августа 1966. Тарту: ТГУ, 6-12.

- $1968=$ Успенский, Борис. Структурная типология языков. Москва: Наука. 
- $1970=$ Успенский, Борис. Проблема универсалий в языкознании. In: Новое в лингвистике, выл. 5: Языковые универсалии. Москва: Прогресс, 5-30.

- 1994 [1983, 1987] = Успенский, Борис. Мифологический аспект русской экспрессивной фразеологий. In: Успенский, Борис А. Избранные труды, T. II: Язык и культура. Москва: Гнозис, 53-128.

\section{Об универсализме в связи с интерпретацией магии в семиотике Юрия Лотмана}

В статье даётся оценка первой фазе универсалистских штудий в семиотике Юрия Лотмана, характеризуемой холизмом, присущим соссюрианской концепции языка, и максимализмом. Проводится анализ поныне неопубликованной лекции 1967 года, в которой функциям текста (в том числе магической) приписывается универсальный статус. Такой угол зрения существенно переосмысливает соссюрианское понимание взаимоотношений между языком и речью. Эта интерпретация магии сравнивается с толкованием того же понятия в статье ""Договор" и "вручение себя" как архетипические модели культуры" от 1981 года, которое существенно противоречит концепции, выработанной в лекции 1967 года. Обе концепции вызывают ряд возражений и, кажется, явно носят деформирующие признаки соответствующих универсалистских теоретических схем.

\section{Universalismist ühenduses maagia käsitusega Juri Lotmani semiootikas}

Artiklis antakse hinnang Juri Lotmani semiootika universalistlike käsitluste esimesele faasile, mida iseloomustab saussure'likust keelekontseptsioonist pärit holism ja maksimalism. Analüüsitakse Juri Lotmani seni avaldamata loengut 1967. aastast, milles teksti funktsioonidele (sh. maagilisele) omistatakse universaalne staatus. Niisugune lähenemisnurk revideerib oluliselt saussure'likke arusaamu keele ja kõne vahekorrast. Seda maagia interpretatsiooni võrreldakse sama mõiste käsitusega Juri Lotmani artiklis “'Leping' ja 'eneseloovutus' kui arhetüüpsed kultuurimudelid" 1981. aastast, mis 1967. a loengus väljatöötatud kontseptsioonile oluliselt vastu räägib. Mõlemad maagiamudelid tekitavad rea vastuväiteid ja näivad ilmselt kandvat neile vastavate universalistlike teoreetiliste skeemide deformeerivaid jälgi. 


\title{
APPENDIX
}

\section{Semiotics of the individual and society. Juri Lotman}

\author{
Lecture IV, December 22, 1967 (excerpt) ${ }^{17}$
}

If we wish to use texts to study society or people, we must first clarify the nature of signs and the rules for their use (these depend on the culture types).

We are accustomed to easily being able to separate, for example, scientific texts from religious texts, etc. We act as if we know how to decipher them in different ways.

We study each of these different texts in different ways. We say that there are various types of signs:

1) natural language signs - we define [these ${ }^{18}$ with the aid of grammar and dictionaries, or we compile these [i.e. a grammar, a dictionary]

2) myth - we assume that it is possible for us to create some kind of rules in order to clarify [= to interpret] the signs and grammar of mythological texts

3) scientific text - but here we do not implement the ways of studying myth.

This seems to be quite obvious. But it is not really the case. We could, for example, take a scientific text and show that in certain situations it could function as a religious text.

Even an everyday phenomenon can acquire the features of myth, or other uncharacteristic features. (Penicillin may function not only as a medicine but also as a mythological unit — as the Redeemer.)

If we make some kind of scientific discovery and start to treat it as the savior in all situations, [then the result is] religion.

It does not suffice to know the text. One must know its function in society. Different texts may fulfill the one function. (A religious function could be fulfilled by sport, war, science, medicines, etc.) There is a certain interdependence between text and function, but this is not a linear one.

17 See footnote 1. Translated by Tiia Raudma.

18 The square brackets contain words added by me (P. L.), which were not present in Marju Lauristin's notes. Italics denote Russian-language words or sentence parts in the text. 
Social function must be differentiated from social texts! If we say that science has replaced religion, this generally means the replacement of texts, because the function of religion has been preserved in society. (An article by a French doctor on the crisis in medicine: the relationship of the patient with the doctor must be religious. A critical relationship hinders the medical effect. It is difficult to be one's own doctor, teacher, adult. Here the relationship of trust [is valid], and this is not based on knowledge.)

[There are] a number of relationships of which some [are such where the individual is in a mutual relationship in the role of] a speaker, and others [where the individual is] in the role of a listener.

$\underline{N O N-S I G N S}^{19}$

I PRACTICE

I am doing something

III SCIENCE

I am obtaining the truth (procedure) $\underline{\text { SIGNS }}$

II MAGIC

Something is being done to $\mathrm{me}^{20}$

IV RELIGION, BELIEF

I am being given the truth

Therefore, we have four functions:

I [Practice]. My activity takes place in the sphere of practical activity, not of signs.

II [Magic]. A situation where [you] yourself are in principle not able to affect anything in practice, you only receive. If you do not feel that the basis on which you are being given something is legitimate (for example, [the unexplained appearance of a] taxi), a magical situation is created.

A person creates a connection between himself and this situation, and with the activity, in order to be deserving of the arrival of the inexplicable gift. A person does much, which cannot be explained on a conscious level, and [which is] practically useless regarding having an effect on things which cannot be influenced. (When the taxi is late, we try "to speed it along" [by pressing our feet against the wall of the car]; [ pushing

19 It is probable that the classification takes into account that the practitioner (I) always has a relationship with non-signed reality, while the scientist (II) - of course, if he is a natural scientist - has this relationship most of the time. In magical and religious relationships, the individual always deals with signified structures. (Note by P. Lepik.)

20 If something is being done to me, which I could just as well do myself, then this relationship is invalid. (Note by the author of the lecture.) 
up against the person in front of us in] the ticket queue before a performance.) Magical function: I hope that something beneficial for me will happen, which [is] inexplicable to me and is something I cannot influence. The activity has a signifying nature, so that $[?=$ and $]$ it demonstrates its trust regarding this unknown power.

III Science. It is assumed that as a result of some procedures, I am able to obtain the truth. Science begins where there is procedure. It is the start of formalism. If the procedure [is] incorrect, the result is not considered to be the truth. In science, it is not the truth that is that important, it is the way to the truth. The giver [is] unnecessary. Regarding giving, a critical attitude [is dominant], [a scientific relationship is characterized by] a nontrusting relationship.

IV Belief. Religion. [This is] also truth, but it is assumed that this [is] held by someone who has to actually give it. The subject is not capable of getting it himself. Truth here is an act of dedication. Activity here has another meaning than it does in science. The giver comes to the fore, the one who is indispensable, and with whom a special relationship of trust is created. [The situation presumes the question:] What should I do in order that I will be given something?

Why is that people [generally] are unable to believe - as in God. There are various reasons. In the case of God, [there is] unlimited trust, which in principle cannot be controlled. (In the case of science, since [the scientist is] himself active, esotericism is inconceivable.) Regarding religion, [it is a case of] a giving situation, [whereas] the question is immediately raised: who are the ones to receive, and who do not. [There is] a need for a particular signed action, in order to be worthy.

I (Practice) and III (Science) [are] speaker [texts]; II (Magic) and IV (Belief) [are] listener [texts].

We can observe how, for example, a scientific text becomes a religious one, or even magical one, how it changes from a speaker text to a listener text.

We can therefore say that on the one hand there is a certain historic typology in action, where [in a certain era] certain types of texts dominate, for example [in history] there are mythological periods, religious periods, scientific periods. [On the other hand, the functions under observation could be a combination:] prayer [can fulfill both] relig[ious $]+[=$ as well as $] \operatorname{mag}[$ ical functions]; religious texts [have] certain scientific functions, etc. 
To be a listener is not to be a remnant from the past. Science cannot fulfill all social functions. There are undoubtedly a number of texts, where a scientific approach can prove to be damaging. The reverse is also true: unlimited faith in some scientific concept gives it a religious function.

Previously [we observed instances, where] the text, in a certain function, always [has] the one meaning. The function of the text may change but it has only one function at a time.

There is a function which is different from the four [previous] functions, which [also] has its own texts.

A text which [is simultaneously] in two languages [has] two simultaneous functions:

1) [in] a play situation two behaviors (= text meanings) [are initiated] simultaneously. The game can be ruined in two ways:

a) the children tend to see the chair covered in tiger stripe fabric as a genuine tiger - no play is initiated

b) the adults are unable to imagine that the chair is a tiger - no play is initiated

2) in art. [Art] also unites at least two [behaviors simultaneously]

If art is interpreted as having a single meaning [we] are unable to comprehend it. We are then unable, based on this, to properly interpret, for example, society.

Why [does] mankind need such a multiplicity of meaning? (Not to be confused with allegorical multiple meanings. For the reader, this means [only] one!) But in the theatre, each [element has] at least two simultaneous meanings. If we believed that there was real life on the stage, the enjoyment of art would disappear completely, [the performance] would become the same as peering through the keyhole. In watching a movie, 1) we become involved just as if the events were real life, but 2) we do not interfere. If we perceive the same text as being religious, we would have switched to one [and only] behavioral system. When Lope de Vega lost consciousness when listening to a mass and imagining the sufferings of Christ, music was for him not art, but religion. Religious attitudes [are] disastrous both in art and in science. 